\title{
Movimento estudantil brasileiro: Práticas militantes na ótica dos Novos Movimentos Sociais
}

The Brazilian student movement: militant practices from the viewpoint of the new social movements

Mouvement des étudiants brésiliens : pratiques militantes dans l'optique des nouveaux mouvements sociaux

\section{Marcos Ribeiro Mesquita}

\section{(2) OpenEdition}

\section{Journals}

Edição electrónica

URL: http://journals.openedition.org/rccs/1151

DOI: $10.4000 /$ rccs. 1151

ISSN: 2182-7435

\section{Editora}

Centro de Estudos Sociais da Universidade de Coimbra

\section{Edição impressa}

Data de publição: 1 Outubro 2003

Paginação: 117-149

ISSN: 0254-1106

\section{Refêrencia eletrónica}

Marcos Ribeiro Mesquita, « Movimento estudantil brasileiro: Práticas militantes na ótica dos Novos Movimentos Sociais », Revista Crítica de Ciências Sociais [Online], 66 | 2003, colocado online no dia 01 outubro 2012, criado a 19 abril 2019. URL : http://journals.openedition.org/rccs/1151 ; DOI : 10.4000/ rccs. 1151

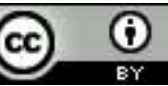




\section{Movimento estudantil brasileiro: Práticas militantes na ótica dos Novos Movimentos Sociais ${ }^{1}$}

Este artigo visa identificar na estrutura e organização do movimento estudantil conteúdos e formas organizativas que nos indiquem o surgimento de uma nova sociabilidade militante. Para tanto, foi necessário analisar as relações entre os diversos grupos organizados do movimento estudantil, desde os mais institucionalizados, àqueles que empreendem outras formas de fazer política. A pluralidade de expressões estudantis, de novos formatos, metodologias e pautas parecem apontar para esta sociabilidade, apesar do forte caráter tradicional que a política estudantil institucional ainda possui.

\section{Introdução}

O movimento estudantil em geral foi bastante ativo e marcou, definitivamente, no século passado, sua presença no cenário político latino-americano. No Brasil, sua trajetória de certa forma remonta grandes momentos históricos, bem como, os principais fóruns e debates acerca da educação e dos modelos de universidade. Além disso, conseguiu, por algum tempo, ser o ator social de maior força e organização, atraindo outros grupos e movimentos sociais.

Sua ação reivindicatória e seu posicionamento político perante o Estado durante a ditadura militar neste país foram cristalizados no imaginário social como o seu grande momento, sendo eleito 1968, o ano que retrata mais expressivamente sua importância. Principalmente nas décadas de 70 e 80, o movimento estudantil brasileiro foi objeto de pesquisa nas diversas áreas de conhecimento, de que são exemplos importantes os trabalhos de Foracchi (1972, 1977), Albuquerque (1977a, 1977b), Sanfelice (1986), Martins Filho $(1987,1996,1998)$ e mais posteriormente Cardoso $(1990,1998) .^{2}$

\footnotetext{
${ }^{1}$ Contendo algumas alterações, este artigo baseia-se numa primeira versão já publicada na Revista de Psicologia Política (2003).

${ }^{2}$ Os diferentes olhares destes autores propiciaram várias análises acerca do movimento, principalmente no que se refere à sua atuação enquanto movimento social de contestação dos anos 60 . Como afirma Scheren-Warren (1998: 57), "as mobilizações coletivas do final da década de 60, principalmente o movimento de 68 , foram terreno fértil para uma grande produção de novas teorias dos movimentos sociais". E é nesse contexto que se inscreve a emergência dos Novos Movimentos Sociais (NMS) que iremos trabalhar mais adiante.
} 
Como uma das expressões do protagonismo juvenil - e por muito tempo, seu termômetro - o movimento estudantil continua apresentando-se, como uma das possibilidades de inserção e atuação política para uma parcela dos estudantes. Para estes, o ingresso na universidade e a participação na vida universitária como escreveu Foracchi,

representam uma situação nova... Abrem-se horizontes de participação que são novos pelas oportunidades que o jovem encontra de conviver com outros que compartilham dos seus problemas, envolvendo-se, na busca comum das alternativas desejadas, criando compromissos semelhantes com a condição que, no momento, define as suas vidas e que é a condição de jovem. (Foracchi, 1972: 74-75)

Porém, devemos considerar que, diferentemente das décadas passadas - onde o movimento estudantil era o único canal de expressão política dos jovens -, atualmente, os estudantes contam com múltiplos e diferenciados canais. Muitos deles sinalizam a emergência de novos atores juvenis que atuam nos mais diversos campos, discutindo e construindo coletivamente políticas públicas que atendam as suas necessidades. As ONG's, os movimentos juvenis de cunho cultural, etc., são espaços outros de inserção destes jovens no cenário que se apresenta.

Assim, estes novos atores juvenis começam a desenhar novos elementos que se expressam através do surgimento de outras demandas de juventude, bem como, de outras formas organizativas. Como afirma Melucci (1997: 12-13), hoje os movimentos juvenis "[...] tomam a forma de uma rede de diferentes grupos, dispersos, fragmentados, imersos na vida diária. Eles são um laboratório no qual novos modelos culturais, formas de relacionamento, [...] são testados e colocados em prática".

Inscritos num outro paradigma de participação e ação coletiva, atualmente, as organizações e os grupos juvenis - incluindo o movimento estudantil - trazem consigo elementos, estratégias e repertórios característicos do referencial teórico dos Novos Movimentos Sociais (NMS) ${ }^{3}$. Este é caracterizado por Sousa (1999: 117), como sendo:

um novo tipo de expressão coletiva que introduz outros atores sociais organizados sob outras referências não ligadas às tradicionais esferas e aos canais 'clássicos' de

\footnotetext{
3 Trabalhos clássicos que desenvolvem de alguma forma os conceitos deste novo paradigma são: "Production de la société", "The New Social Movements: A Theoretical Approach" e "Partidos politicos y nuevos movimientos sociales" de autores significativos desta corrente, respectivamente, Touraine, Melucci e Offe.
} 
representação social (partidos, governos, sindicatos, etc.), redescobrindo novos modos de intervenção social que exigiam um novo olhar sobre a expressão política do cidadão comum.

Como nos sugeriu anteriormente Scheren-Warren (1998), os movimentos estudantis de 68 foram marcos importantes para a construção desse novo paradigma. Este, contrapondo-se às teorias baseadas na lógica racional e estratégica dos atores, deu ênfase a elementos como a cultura, lutas sociais cotidianas, identidade, etc. Assim, tomaremos como eixo de nossa análise do movimento estudantil a perspectiva da teoria dos NMS.

Pensando o movimento estudantil a partir deste eixo, das transformações sociais ocorridas nos últimos anos e das interlocuções que o mesmo estabelece com outros movimentos juvenis, queremos pensar: até que ponto, a diversidade de redes juvenis existentes vem influenciando a prática e as estratégias militantes dos estudantes? Ou, de outra forma, como as novas sociabilidades emergentes no meio juvenil colaboram na formação de uma nova sociabilidade militante no interior do movimento estudantil?

Este artigo pretende analisar o movimento estudantil atual considerando suas diferentes expressões e identificar em sua estrutura e dinâmica de organização, elementos, práticas e conteúdos que nos indiquem o surgimento de uma nova sociabilidade militante.

Para tanto, realizamos uma pesquisa de campo contemplando dois momentos diferentes, a saber: a) a participação em dois encontros nacionais de estudantes; b) coleta de dados documentais das entidades estudantis.

Num primeiro momento, realizamos nossa pesquisa no $46 .{ }^{\circ}$ Congresso da União Nacional dos Estudantes - CONUNE -, ocorrido na cidade de Belo Horizonte (MG), em julho de 1999; e posteriormente, no Congresso Nacional dos Estudantes de Agronomia - CONEA - realizado na cidade de Pelotas (RS), em setembro deste mesmo ano.

Nesta etapa, foram entrevistados 17 estudantes de todo o país, divididos a partir da representatividade dos grupos e tendências do movimento estudantil geral, bem como da representação das Executivas de Curso, contemplando o movimento específico de área. Os entrevistados representavam a pluralidade de grupos e orientações políticas existentes naqueles congressos, sendo eles militantes independentes, libertários, dirigentes de entidades, e pertencente às diferentes tendências.

Num segundo momento, realizamos uma coleta de dados documentais (fotos, arquivos, atas de seminários e reuniões, etc.). Neste artigo, daremos 
ênfase às entrevistas realizadas com os militantes nos respectivos encontros, e à medida em que for preciso, complementaremos nossas reflexões com alguns destes dados documentais.

$\mathrm{Na}$ análise das entrevistas fizemos, inicialmente, um trabalho para identificar possíveis categorias implícitas nos variados discursos dos militantes. Posteriormente, confrontamos estas categorias que emergiram nos discursos com algumas outras já preestabelecidas por nós a partir dos objetivos desta pesquisa e das observações realizadas em campo. Neste exercício, demarcamos um eixo de análise e nos centramos em algumas categorias, das quais quatro delas estarão presentes neste artigo.

\section{Analisando o movimento...}

Analisar o movimento estudantil é antes de tudo, analisar um movimento plural, capaz de se expressar através de vários grupos que se potencializam no cotidiano da condição estudantil. Poderíamos afirmar que este não se limita a suas organizações estudantis e formais, mas se manifesta na própria dinâmica de criação de interesses e pautas que - transformadas diariamente pela realidade estudantil, pelas relações universitárias e pela sociedade civil pode ser capaz de mobilizar os estudantes. Assim, acreditamos que não exista um movimento estudantil unitário, mas movimentos estudantis que se inter-relacionam e se intercruzam.

Nesta pluralidade existente, o movimento agrega um número infinito de tribos e grupos em seu interior, desde aqueles que se manifestam através de tendências orgânicas - geralmente ligados a um partido político -, até aqueles que expressam interesses temáticos e mais localizados - como o grupo de estudantes negros e as Executivas de Curso, por exemplo. Existem ainda aqueles que apesar terem uma organização de grupo, não possuem vínculos partidários. É o caso dos independentes e dos anarquistas.

Por outro lado, a existência desta pluralidade muitas vezes é ofuscada dada a capacidade de articulação e de estratégias das entidades estudantis clássicas, que imprimem um estilo, um modo de fazer política e militância que não contemplam, ou têm dificuldades de aceitar, novas maneiras de expressão estudantil, ficando estas últimas, muitas vezes marginalizadas.

Concordando com Foracchi (1977:230) entendemos que,

não se pode compreender sociologicamente o movimento estudantil apenas em função das posições defendidas pela sua vanguarda. É necessário investigar sob que condições se estabelece a comunicação entre a cúpula e a base e de que forma as decisões desta traduzem as reivindicações daquela. 
Podemos destacar também que o movimento estudantil, nos últimos anos, absorveu várias das tendências e temáticas dos novos movimentos sociais. Além do aparecimento das diversas expressões estudantis, surgem também de maneira expressiva temas mais amplos como a discussão da cultura, do meio ambiente, da paz, dos movimentos de minoria, entre outros. Porém, apesar disso, o movimento estudantil não consegue aglutinar boa parte dos estudantes, seja na realização de suas assembléias, seja nas passeatas etc.

O movimento passa assim, por uma crise de representatividade e organicidade que se manifesta na sua intervenção fragmentada e na pouca expressividade entre os estudantes. Existem momentos em que esta crise se põe mais em evidência que outros. Entre os poucos momentos de maior fluxo de participação dos estudantes nos últimos anos, destacamos o Impeachment.

Pensando nesta configuração, decidimos aprofundar a análise do movimento estudantil atual, que pudesse nos mostrar as ligações existentes, entre a realidade de sua prática política, e a constatação da falta de participação dos estudantes no interior de suas entidades e nas lutas que delas advém. Qual o limite dessa falta de participação? A falta de participação dos estudantes é constatada em que espaços do movimento estudantil? Estaria sendo o movimento, portador de projetos coletivos e mobilizadores entre os estudantes?

Para trabalhar estas questões, nos apoiamos em algumas categorias extraídas a partir da pesquisa participante e das entrevistas realizadas com os militantes no $46 .{ }^{\circ}$ CONUNE. Deste modo, problematizaremos o movimento a partir das seguintes dimensões: a) o movimento estudantil e os estudantes; b) o movimento estudantil e os partidos políticos; c) o movimento estudantil e os seus ideários; e d) o surgimento de novas linguagens e práticas emergentes em seu interior.

A decisão de analisar o movimento estudantil atual tendo como um dos panos de fundo o CONUNE, foi dada pelo entendimento que temos do mesmo enquanto espaço representativo e aglutinador, onde os diversos grupos se manifestam, marcando seu campo político. Além disso, entendemos que os congressos estudantis, não se limitam a um campo de disputa política por parte dos grupos organizados com vistas a imprimir sua marca na direção do movimento; ou a um espaço somente deliberativo onde os estudantes tomam posições políticas para demarcar suas futuras ações, suas estratégias, sua agenda etc. Os congressos contemplam todas estas dimensões, mas também são espaços onde se localiza e se cultiva a tradição, entendida aqui como a consolidação da experiência coletiva que se faz através da repetição e, por conseqüência, da recordação desse fazer, dessa experiência. Esta consolidação da experiência coletiva "garante o acesso do indi- 
víduo à dimensão de sua ancestralidade, tradição que pulsa em cada instante do 'agora'. A repetição em um sentido preciso garante a 'recordação coletiva', substância mesma da tradição: recordação é a anamnese da experiência coletiva na sua forma social" (Matos, 1989: 31).

Apesar do cunho muitas vezes reprodutivista e difuso, os congressos conseguem ser, ainda, um espaço de expressão de novidades, e às vezes, de ruptura... Ou seja, um locus onde se permite a criação e fortalecimento de novas práticas, de um novo agir coletivo.

\subsection{O movimento estudantil e os estudantes}

Burocratizado, hierarquizado, centralizador, partidarizado, ultrapassado... Estas são algumas das representações (inclusive dos militantes) acerca do movimento estudantil que, de certa forma, se cristalizam enquanto justificativas do distanciamento entre os estudantes e suas entidades. Como uma das temáticas mais debatidas e refletidas por estes nos últimos anos, a questão da representatividade do movimento estudantil vem sendo uma preocupação constante.

Cada grupo ou tendência, a partir de suas concepções e olhares, formula seus diagnósticos, suas avaliações... E apesar das diferenças existentes entre estes, o discurso parece comum.

De alguma maneira, isso se refletiu na construção de propostas, críticas e intervenções no $46 .^{\circ}$ CONUNE. Todas as teses se referiram à crise do movimento estudantil enquanto ator catalisador de uma ação coletiva mais efetiva. Os sintomas do enfraquecimento da representatividade das entidades estavam inscritos na fala dos militantes. Havia uma manifestação de descontentamento...

Com uma diversidade de olhares, os militantes entrevistados no congresso explicavam o distanciamento dos estudantes, ora a partir de aspectos externos (crise dos movimentos sociais, individualismo, etc.), ora a partir de aspectos e fatores internos (burocracia e aparelhamento das entidades, por exemplo). No discurso de cada um deles, evidencia-se o esgotamento de suas práticas políticas, a necessidade de realizar uma reestruturação das formas tradicionais de fazer política, apesar da dificuldade de fazê-la.

Independente das justificativas e diferenças de avaliação assumidas por cada grupo, a percepção do distanciamento entre estudantes/entidades ficou visível. Além disso, esta discussão está intimamente ligada à outra de caráter estrutural do próprio movimento como veremos a seguir: a influência dos partidos no interior do movimento estudantil. Esses dois temas se intercruzam e não podemos dissociá-los. 
$\mathrm{Na}$ fala do militante de uma das tendências de oposição ao grupo majoritário da direção da $\mathrm{UNE}^{4}$, pudemos perceber a crítica em relação à entidade, que como relata, "aparelha" o movimento e não formula alternativas para que os estudantes possam intervir de maneira efetiva:

Bom, é aquilo que eu disse. Hoje o movimento estudantil está distante, há uma descrença muito grande por parte da base estudantil, especialmente quanto às entidades. A UNE está totalmente desacreditada, muitos estudantes têm repulsa da UNE, tanto é que se você chama uma atividade numa universidade, se a UNE está envolvida na organização é quase certeza que não vai ter sucesso tal atividade, porque é a UNE que está promovendo. Então hoje o movimento estudantil em relação aos estudantes assume uma condição complicadíssima. [...] Só que o movimento estudantil a partir do aparelhamento das entidades que o PC do B especialmente faz, assumiu uma postura de se distanciar dos estudantes, porque não é interessante que os estudantes intervenham na entidade, isso não é interessante. Não é interessante que o estudante vá lá e cobre da UNE uma atuação de uma determinada maneira, não é interessante que os estudantes vão lá e queiram saber o que acontece dentro da entidade, e quem faz o movimento estudantil no Brasil são as entidades, se a entidade está distante [...] (militante 1 - Esquerda do Partido dos Trabalhadores/PT)

Como vimos, o desgaste das entidades se corporifica no descrédito e na falta de participação dos estudantes nos espaços instituídos pelo movimento estudantil geral, que já não traz consigo mecanismos ou estratégias que mobilizem ações coletivas e simbólicas que os envolvam. A distância entre estudantes/entidades, muito se dá pelo fato do movimento estudantil não criar ou recriar espaços de participação para os estudantes.

A falta de um elo identitário que sirva de mediação entre o ideário do movimento estudantil e as aspirações estudantis (considerando as suas várias especificidades) deveria ser motivo de reflexão dos militantes, visto que, atualmente, poucos são os estudantes que se identificam com o movimento. Essa questão se torna pertinente, na medida em que a existência de uma comunicação mínima entre os estudantes e suas entidades se faz necessária para que o movimento estudantil seja, de fato, representativo.

Além disso, a estrutura das entidades, com todas as suas estratificações, já não consegue contemplar as novas características e demandas juvenis existentes, limitando a participação dos estudantes, que não se vêem "enquadrados” neste modelo de organização institucionalizado. Nesse sentido, é

\footnotetext{
${ }^{4}$ A União da Juventude Socialista - UJS, juventude partidária do Partido Comunista do Brasil é, atualmente, a tendência de maior força no movimento estudantil brasileiro, estando ininterruptamente como força majoritária na direção da União Nacional dos Estudantes - UNE, desde 91.
} 
real e pertinente a crítica feita sobre a questão estrutural do movimento, que mesmo tentando se adaptar aos novos modelos de organização, mantém ainda elementos característicos de uma estrutura centralizada e hierárquica.

Apesar de ter incorporado mecanismos como a proporcionalidade qualificada - que garante a representatividade das variadas tendências em sua diretoria - e a formação de secretarias temáticas que correspondem às demandas atuais e gerais (secretaria de mulheres, anti-racismo, cultura, meio-ambiente, etc.), o formato fortemente institucionalizado da entidade enrijece a dinâmica própria do movimento, bloqueando as possíveis experiências positivas que poderiam advir desta nova estrutura. A própria incorporação/institucionalização destas novas temáticas no movimento a partir da formação de secretarias, denuncia a falta de um modelo estrutural mais contemporâneo no movimento. Mesmo na tentativa de incorporar temáticas emergentes, impõe um modelo tradicional nos novos conteúdos, formatando-os em secretarias.

Porém, também não devemos perder de vista as transformações sociais que ocorreram nos últimos anos. Se o movimento não aglutina e nem mobiliza tanto os estudantes, como no passado, isso se torna mais problemático numa conjuntura marcada pelo neoliberalismo. A realidade dos últimos 20 anos de uma sociedade baseada na concorrência - imposta pelas leis de mercado - no individualismo, e numa "inversão de valores" subjacentes a uma ideologia conservadora e estruturante do status quo, faz parte da retórica estudantil para explicar a falta de participação dos estudantes e o distanciamento destes das entidades. No discurso abaixo, fica visível essa problemática que explicita as dimensões conjunturais e de valores.

Se eu for dizer pra você no geral existe uma distância muito grande. O estudante hoje, o universitário - que é o que eu posso te falar, não posso te falar do estudante secundarista - mas o universitário hoje está muito preocupado em entrar na universidade e conseguir uma bolsa que é muito difícil e pesa muito no currículo, se formar e conseguir um emprego, ou então entrar no mestrado ou pós-graduação. A maioria dos estudantes hoje, infelizmente, apesar de terem conhecimento do que tá acontecendo, infelizmente, acabam olhando para o próprio umbigo. A crise é grande, o emprego é difícil, uma bolsa na universidade é difícil demais, está ficando cada dia mais difícil, o corte de verbas na universidade é grande. Só que o estudante não para pra ver que o corte de verbas da universidade está sendo grande. Ele para pra ver que ele não tem uma bolsa de trabalho, existe um individualismo. Eu acho que existe uma relação de distância, e essa relação de distância é um dos fatores fundamentais para a crise que o movimento estudantil está vivendo hoje. (militante 2 UJS-PC do B) 
O discurso reflete a ansiedade da militante que não vê no movimento estudantil a capacidade de "quebrar o muro", de "romper as barreiras" que impedem o estudante de notar que o seu desempenho individual está intimamente ligado a questões gerais de conjuntura que precisam ser vistas coletivamente.

Existe neste discurso, a idéia de uma inexistência, ou talvez, de uma pouca visibilidade do protagonismo estudantil, causado por diversos fatores externos ao movimento e comuns a um cenário de desmobilização da maioria dos atores e organizações da sociedade civil. Pontuada como característica dos mais variados setores sociais, este argumento explica em parte a questão da falta de participação, visto que não se pode deixar de responsabilizar o próprio movimento por suas próprias ações, que muitas vezes, reforçam este distanciamento.

Como afirmamos anteriormente, um outro aspecto está intimamente ligado no distanciamento já explicitado: a partidarização do movimento, mais entendida como o "aparelhamento das entidades" pelos partidos políticos. Essa discussão coloca em foco outra questão: a institucionalização no movimento de uma prática política reprodutora de um babitus ${ }^{5}$ que garante na sua essência uma profissionalização da própria política.

Mas qual a real influência das organizações partidárias dentro do movimento estudantil? Como estas se expressam e são percebidas pelos próprios militantes?

\subsection{O movimento estudantil e os partidos políticos}

Todos os nossos entrevistados enfatizam a existência de uma forte relação do movimento estudantil com os partidos - em sua maioria de esquerda e que têm sua presença expressa na configuração de diversas tendências que imprimem seu ideário, suas estratégias, sua visão de mundo, sua proposta global de sociedade. Estas, com suas reais diferenças entre si representam para muitos estudantes (e militantes), o conflito manifesto no cotidiano estudantil, e são consideradas como um dos principais fatores que contribuem para o alargamento da distância entre estudantes/entidades.

Com um discurso que prega a unidade do movimento para reconquistar a representatividade, a tendência majoritária da direção da UNE no $46 .^{\circ}$ Congresso, apostou num movimento baseado na união de forças políticas. Com o slogan: "A UNE é união, não é partido não" a tese Refazendo criou um discurso de um movimento estudantil unitário e apartidário. Essa idéia

\footnotetext{
${ }_{5}$ Conceito de Bourdieu que se refere um sistema de disposições adquiridas pelo indivíduo durante seu processo de socialização. Para o autor, as disposições podem ser atitudes, inclinações a perceber sentir, fazer e pensar, comportamentos e valores aprendidos e interiorizados.
} 
ficou explícita nos diversos cartazes e faixas dispostas no congresso. No discurso de sua representante, como veremos abaixo, essa proposição se confirma, além de mostrar abertamente os conflitos inerentes à prática militante.

E uma dificuldade muito maior dentro da própria militância é a questão de a gente ter que conviver com muitas divergências. O objetivo, certo, das correntes que existem no movimento na teoria é o mesmo, mas a prática nem sempre direciona para esse objetivo comum. Então existem pessoas mais radicais, mais estreitas. É difícil você conviver, é difícil você procurar uma unidade que é totalmente necessária. É a unidade que pode ajudar a resolver essa crise que existe no movimento estudantil hoje. Então assim, você unir essas forças, argumentar com elas, fazer com que elas abram pra certas propostas como a gente abre, acaba sendo um pouco difícil, desgasta, estressa. No caso aqui do CONUNE, a gente participa de grupo de discussão e as pessoas fogem do tema pra falar mal da diretoria da UNE. Você está discutindo a comunicação e o pessoal vem falar do PC do B. Ninguém tá discutindo o PC do B, nem o PT nem o PSTU, a gente está querendo proposta pra ver como é que a comunicação da UNE melhora, como é que a UNE chega mais perto do estudante, se está tendo debilidade vamos ver porque está tendo debilidade, qual a melhor maneira de resolver, quais são as propostas, como é que a gente encaminha essas propostas. (militante 2 - UJS/PC do B).

O discurso da unidade entre as tendências é um eixo central e pertinente na fala da militante. Ao mesmo tempo, é um discurso que não aparece na fala dos militantes de outros grupos do movimento, o que pode sinalizar possíveis diferenças de perspectiva sobre o tema. Pensamos que para problematizar a questão da unidade no movimento teríamos que entender as representações que cada tendência faz acerca da mesma, pois, esse discurso também pode esconder uma série de diferenças existentes no modo em que cada grupo faz sua política. O movimento estudantil também se caracteriza pelo fato de ter em si a capacidade de manifestar sua pluralidade. A questão da unidade é pertinente, desde que, resguardado o espaço para a manifestação da diferença.

Pensando na temática do apartidarismo temos que pontuar que o discurso se torna ambíguo e difuso, na medida em que, é mediada por uma tendência que se serve do partido para se manter enquanto grupo político na direção da entidade e que em vários momentos tem defendido a importância do partido enquanto grupo que organiza os estudantes dentro do movimento. Coloca-se como "neutra" ao falar da "unidade" e do "apartidarismo". Fala destes dois elementos de um lugar que não é neutro. 
Mas se este discurso é ambíguo, a sua existência mostra, por outro lado, que a influência dos partidos, de certa forma, desgastou as entidades estudantis e acaba por se tornar signo de uma reação à excessiva partidarização existente no movimento; a lógica do apartidarismo, desta forma, acaba tendo uma aceitação muito forte no meio estudantil, principalmente entre os menos institucionalizados.

Neste sentido, podemos observar que a maioria das teses e falas dos entrevistados reproduz o discurso da amenização da influência partidária e de toda uma cultura criada e conservada por ela. Mesmo aquelas tendências mais tradicionais [os diversos grupos no interior do Partido dos Trabalhadores (PT), o PC do B e o Partido Socialista dos Trabalhadores Unificados (PSTU) ] moderam quando tocam neste ponto. Porém, não sinaliza a "extinção" da influência do partido enquanto orientação para a ação do movimento estudantil. Os entrevistados, apesar de entenderem que existem conflitos que demarcam as fronteiras de espaço do movimento e do partido, não vêem este último como um problema em si. O partido é um espaço político que organiza, orienta e estimula os estudantes. A prática do aparelhamento da entidade estudantil pelos partidos é que fica condenada pela maioria dos militantes, como veremos a seguir:

Eu não sou contra um movimento estudantil partidário, sabe, que se identifica com um partido. Eu sou filiada ao PT e me identifico com ele e não tenho vergonha de dizer isso no centro acadêmico. Não vejo problema. Eu acredito que você só consegue ter uma linha organizada dentro de um movimento se você tiver um partido. O problema está quando você aparelha a entidade, você começa a usar a entidade só para o seu partido e esquece o resto. E esquece as outras pessoas que não são do seu partido e que também acha que tem alguma coisa pra contribuir. Não sou contra ter partido, não sou contra a UNE ser partidária, o problema é o aparelhamento. Ela fica completamente atrelada ao partido e aí não fica democrática, não respeita o resto. (militante 3 - Esquerda do PT)

[...] Veja, eu sou daquelas pessoas que acha que o movimento estudantil brasileiro está ostensivamente partidarizado, e isso tem feito com que a UNE perdesse sua representatividade, não só a UNE mas as organizações estudantis tem perdido essa representatividade, por conta que elas não tem uma agenda própria do movimento, uma agenda própria da universidade, uma agenda própria dos estudantes; e acabam impondo em função dessa presença do partidarismo a agenda dos partidos políticos. Isso acaba afastando um pouco o estudante que não tem nenhum vínculo partidário. Agora por outro lado, nós não podemos por conta disso, de uma leitura dessa, ter um tipo de reflexão e de discurso apartidário, apolítico, porque não é isso. [...] Eu 
acho que o problema não é exatamente a presença da militância partidária dentro do movimento estudantil; é você aparelhar o movimento, é você aparelhar as entidades estudantis pra transformá-la num braço, numa correia de transmissão do pensamento partidário. E é nesse sentido que eu acho que o movimento estudantil brasileiro está ostensivamente partidarizado. A UNE precisa voltar a ter uma agenda própria para a universidade, uma agenda própria para os estudantes. (militante 4 - Unidade na Luta/PT)

O último discurso, feito por um dos dirigentes da própria UNE, explicita a falta de uma formulação política que contemple uma agenda para os problemas da própria universidade. Afinal, a questão específica do movimento estudantil - a educação - e de maneira especial, a universidade, é o grande eixo que une os militantes. Nesse sentido, o entrevistado aponta para a necessidade do movimento construir rapidamente a sua própria pauta, a partir das necessidades dos estudantes, do movimento, da conjuntura e realidade latentes, colocadas como desafios. A reforma universitária, a avaliação institucional, entre outros, podem ser elementos de uma pauta do movimento que, interligadas a outras reivindicações políticas e sociais mais amplas, podem transformar-se em elementos de luta dos estudantes. Na falta de uma agenda clara, impõe-se a agenda dos partidos.

A compreensão de fim e meio no partido é, portanto, assimilada no interior das entidades estudantis e qualificam a chamada "instrumentalização das entidades”. A questão da organização partidária no movimento estudantil se torna então, central para compreendermos a dinâmica desse movimento hoje. Os entrevistados admitem que eles orientam, politizam, criam uma autonomia no pensar. Porém, ao mesmo tempo, foi criado no movimento estudantil brasileiro uma cultura partidária de tamanha expressão, que acabou imprimindo uma lógica e dinâmica própria, se sobrepondo e, muitas vezes, abafando as muitas iniciativas criativas organizadas pelos estudantes, "paralisando" por assim dizer, o "movimento". A partidarização cria um estilo de intervenção que dificulta o surgimento de qualquer outra forma de manifestação ou expressão, limitando a própria forma de intervenção estudantil.

Esse estilo de intervenção, baseado na profissionalização da política, se caracteriza por um discurso de convencimento, onde os militantes - muitas vezes com um espírito vanguardista - vão ao encontro dos estudantes. Uma linguagem caracterizada pela estratégia do convencimento, pois parte de uma concepção hierarquizada da compreensão dos fatos. 
Como afirma Bourdieu (1998: 194),

a medida em que a política se 'profissionaliza' e que os partidos se 'burocratizam', a luta pelo poder político de mobilização tende cada vez mais a tornar-se uma competição a dois níveis: é do resultado da concorrência pelo poder sobre o aparelho que depende a escolha daqueles que poderão entrar na luta pela conquista dos simples laicos - o mesmo é dizer que a luta pelo monopólio de elaboração [...] está cada vez mais reservada aos profissionais.

Essa dinâmica onde os militantes se percebem enquanto vanguarda - elaboradores de um discurso muitas vezes fechado - distancia cada vez mais aqueles que não participam deste campo político. Para estes estudantes, as regras do jogo são outras.

Assim, importante se faz estabelecer outras formas de linguagem e comunicação no interior do movimento, de maneira a não se institucionalizar ainda mais o discurso dos militantes partidarizados, como o único possível.

Mas num quadro tão heterogêneo e com tantas disputas políticas em jogo, como pensar e analisar a formação ou constituição de um ideário do movimento estudantil?

\subsection{O movimento estudantil e seus ideários}

Como um espaço plural, o movimento estudantil expressa um ideário que contempla aspectos e pautas tanto classistas, quanto transclassistas; desde aspectos mais ligados a uma questão geral, até propostas e pautas mais setorizadas. Um misto de concepções e estratégias diferentes.

De maneira sintética as questões convergem para 3 pontos principais: a) reestruturação da entidade; b) ampliação das temáticas no interior do movimento expressa através de lutas amplas, porém setorizadas; e c) lutas pela educação (mais fortemente a defesa das universidades) e contra o neoliberalismo, que resgatam aspectos mais clássicos e históricos do movimento estudantil.

Esse tripé que sustenta o ideário do movimento é, de certa maneira, uma construção ideal, um modelo. Na dinâmica do cotidiano os diferentes grupos que atuam diretamente no movimento privilegiam uma ou outra dimensão acima colocada, ou intercruzam-nas a partir de suas necessidades. Desta forma, alguns conflitos podem ser ocasionados neste processo de disputa e encaminhamento (na prática) das pautas. Contudo, mais conflitante que o conteúdo é a metodologia que cada grupo segue.

Indagados sobre quais as prioridades do movimento estudantil atual, a maioria dos militantes entrevistados pautou a defesa da educação brasi- 
leira, e mais especificamente, a defesa das universidades, manifestando a compreensão do momento de crise pela qual a universidade pública passa de legitimidade e representação (ver Santos, 1999), além de financiamento. Aliado a esta, está a luta contra uma política econômica que gera menos qualidade de vida e carência de serviços básicos como educação e saúde.

A perda de sentimento da "coisa pública" e da qualidade das condições de trabalho e ensino justificam a existência desta assertiva no discurso estudantil. O discurso mostra que os militantes "sentem na pele" o sucateamento das universidades e estão conscientes da importância que ela tem para o desenvolvimento e soberania nacional. Revela também, que a pauta de lutas dos últimos congressos foi assimilada com propriedade pelos jovens militantes que quando têm oportunidade assim o demonstram. O primeiro discurso abaixo mostra visivelmente esta interpretação.

Eu penso que a prioridade central do movimento estudantil hoje em razão da política educacional desse governo que é claramente privatista, de sucateamento das universidades, é a defesa da universidade pública, gratuita e de qualidade, e do sistema nacional de ensino superior. Porque que eu digo sistema nacional de ensino superior? Eu sempre digo, costumo dizer que o governo brasileiro, um governo que abre mão de ter um ensino público, uma universidade pública, que produz ciência e tecnologia, que produz conhecimento, é um governo que abre mão de sua soberania nacional. Acho que o que precede de você abrir mão da soberania de um país, a soberania de uma pátria, é você abrir mão de produzir conhecimento. E o governo brasileiro já fez uma opção clara por não produzir conhecimento autônomo, por não produzir conhecimento de ponta. Isso se revela no sucateamento das universidades, isso se revela em não ter uma política para financiar os estudos dos estudantes carentes, dos estudantes que não podem pagar mensalidade, das universidades pagas, então enfim, o governo fez essa opção. Então na minha opinião, a grande causa da UNE hoje é a defesa da universidade pública, do ensino público, gratuito e de qualidade, do sistema nacional de ensino superior que está seriamente ameaçado com o projeto de lei do governo, que não altera no texto o artigo 207 da constituição, mas altera na essência, quebra a indissociabilidade do ensino, da pesquisa, e da extensão, porque cria uma concorrência selvagem entre as instituições de ensino através do contrato de gestão que esse projeto de lei institui. Então, portanto, eu acho que essa é a bandeira de luta maior". (militante 4 - Unidade na Luta/PT)

Vários entrevistados se reportaram à questão da defesa da universidade pública e poucos incluíram a universidade privada nos seus questionamentos. Independente das orientações partidárias e da dinâmica 
própria de cada tendência, esse discurso invariavelmente se repete. $O$ realce dado ao problema da realidade da universidade pública pode ser facilmente compreendido, se visto os excessivos projetos de privatização, encaminhados pelo governo federal, e a política de financiamento que impossibilita uma maior autonomia das universidades para a construção do conhecimento. Os militantes, assim, reivindicam uma universidade que seja de fato: pública, gratuita, de qualidade e democrática. Porém, fica o questionamento: se a maioria dos estudantes brasileiros está hoje em universidades privadas, não seria o momento do movimento também discutir com afinco a realidade difícil por quais passam os estudantes destas universidades? 6

Todos os discursos sinalizam para outras questões que também são constituintes do ideário do movimento estudantil atual. A redemocratização das entidades estudantis (sinalizada pela proposição das Diretas na UNE), questões relativas a criação de políticas de juventude e a luta contra o neoliberalismo (sinalizada pela reivindicação do Fora FHC, Fora FMI) são dimensões outras que - com a defesa da universidade - se somam ao rol de lutas e prioridades do movimento. Aprofundaremos alguns destes tópicos.

Priorizar a independência da UNE aparece aqui como um caminho para a defesa do interesse juvenil que emerge das dificuldades da sociedade do trabalho. Permite uma aproximação maior com a vulnerabilidade e os enfrentamentos sofridos pelo jovem devido à falta de políticas públicas. Uma política para a juventude é uma reivindicação que revela a compreensão dos estudantes de que a esfera pública está sendo abandonada em benefício de interesses localizados e afastados da grande maioria dos jovens.

Convencidos da necessidade de criar um espaço dedicado à discussão de políticas públicas de juventude, os estudantes fizeram com que o $46 .^{\circ}$ CONUNE assumisse a temática como meio de aproximação de questões mais gerais e, por verem nela representada a preocupação de boa parte da categoria estudantil. Nas reuniões temáticas realizadas no congresso, onde estudantes e debatedores se posicionavam, a conceituação de política pública foi amplamente comentada. A idéia de uma política de participação como

\footnotetext{
${ }^{6}$ Segundo o Ministério da Educação, existem no país 1.208 instituições de ensino superior privadas, incluindo com fins lucrativos, sem fins lucrativos, comunitárias, confessionais e filantrópicas. Em 1997, havia 1,9 milhão de estudantes no ensino superior - 58,4\% deles em escolas privadas. Em 2001, eram 3 milhões - 69\% deles em escolas privadas. A previsão é que chegue a 10 milhões, em 2010. Dados publicados na Folha de São Paulo de 03 de agosto de 2003 mostram que nos últimos dois anos as instituições privadas aumentaram em $45 \%$ - 544 foram autorizadas a funcionar, ou seja, um estabelecimento a cada 1,2 dia.
} 
agente de criação de projetos a serem desenvolvidos pelo poder público marca a diferença entre o estágio fortemente reivindicatório do passado e o caráter propositivo do presente:

Quando a gente fala de políticas para a juventude, a gente não tá falando só da relação de status quo e implementação de políticas para o jovem [...] Políticas para o jovem o projeto Rondon colocava, a China comunista ainda coloca [...] e isso a gente é contra, nós temos que ser contra. Agora, por outro lado, tem uma concepção de desenvolvimento sustentável local que a gente acha que tem que implementar [...] e dentro dessa discussão de desenvolvimento sustentável, a gente tem os cortes que são os grupos vulneráveis ou vulnerabilizados, que é a criança e adolescente, a mulher, o idoso, os jovens [...]; e para isso a gente tem que ter uma política específica. [...] O jovem de 15 a 29 anos - o adulto jovem - tem as suas especificidades; o jovem tem que ter política de primeiro emprego, tem que ter política de integração, política de participação, e para isso ele tem que ter mecanismos pra acontecer e fazer isso. E os mecanismos que nós achamos ideais são os fóruns de participação, ou seja, os conselhos e as comissões onde as entidades de juventude possam se representar. Essa é a proposta de política de juventude (Integrante do Grupo de discussão sobre políticas públicas de juventude). ${ }^{7}$

Se nos anos 60 a ascensão social via um diploma universitário era uma expectativa da classe média da qual basicamente o movimento estudantil universitário era proveniente, no início do novo século, o trabalho e a qualificação são as reivindicações realistas contra a exclusão de jovens inseridos num sistema de ensino democratizado nas últimas décadas, mas que não responde à falta de uma mobilidade social cada vez mais dificultada pelas políticas neoliberais:

A luta pelo primeiro emprego, a luta pela qualificação do jovem brasileiro pra enfrentar um mundo globalizado que não é uma questão da gente aceitar ou deixar de aceitar. A globalização está aí, está posta e se a gente não se enquadrar a essa nova realidade

\footnotetext{
7 O Projeto Rondon, experiência surgida na década de 60, tinha o objetivo de integrar regiões distantes do país através de políticas de intercâmbio cultural através da universidade. A integração nacional era um objetivo perseguido idealisticamente pela juventude. Podemos afirmar que, "os desafios de integrar, ocupar e desenvolver, com ênfase na ação comunitária, o imenso espaço amazônico brasileiro e as demais regiões do país, por intermédio da ação integrada da Universidade, dos universitários, da comunidade e dos três níveis de governo, motivou estes segmentos da sociedade na consecução de uma idéia simples, porém densa em idealismo, voluntarismo e solidariedade, que empolgou brasileiros de diferentes regiões, condições sociais e crenças políticas" (ver: http://www.uvanet.br/projeto_rondon/novo_rod.html). Um aspecto importante deste projeto era a aproximação do universitário a realidade de seu país, tomando como centro a missão da universidade em não só desenvolver conhecimento, mas de "aplicá-lo" no seu cotidiano. O Projeto Rondon existiu por 22 anos sendo extinto em 1989.
} 
extremamente competitiva e virtual nós vamos também ficar como seres humanos passados pra trás. A grande proposta para o terceiro milênio em nosso país é o jovem se qualificar humanísticamente, intelectualmente pra vencer os desafios que estão postos dentro dessa sociedade extremamente competitiva. (militante 5 - Juventude do Partido da Social Democracia Brasileira - PSDB)

Pode-se afirmar que cresce entre os estudantes uma consciência de interligação com outros grupos juvenis e a necessidade de em conjunto criar políticas de juventude que contemplem necessidades dos seus vários setores. A formação de seminários nacionais, a articulação do Acampamento da Juventude no Fórum Social Mundial, a experiência das secretarias de juventude nos governos populares, tem sido fatores muito positivos para o fortalecimento destas redes de políticas de juventude que emergem nos últimos anos. A luta pela conquista de direitos da juventude também é pauta dos estudantes que já não se diferenciam tanto em termos de oportunidade (ou falta dela!) de outros grupos juvenis.

Outro destaque no discurso dos militantes foi o enfrentamento ao governo federal. Os mesmos viram na ação mobilizadora a única maneira de romper com a estrutura social dominante e capitalista, e ampliar os canais de participação dos estudantes na defesa da educação e da universidade pública brasileira.

Eu acho que a UNE na década de 90 teve um marco que foi o Fora Collor. Acho que depois a UNE não conseguiu articular, como deveria ter articulado o embate com o governo. Inclusive porque não fez oposição ao Itamar, aceitou o novo pacto da burguesia. No governo FHC, no primeiro mandato, o movimento estudantil teve numa posição muito defensiva. Participou de alguns debates na defesa da universidade [...] Depois veio o problema de não assumir a greve das Federais e hoje nós temos uma grande tentativa de retomar o movimento de massa do Fora FHC, Fora FMI. É a nova linha central da União Nacional dos Estudantes. (militante 6 PSTU)

Bom, deveria se tirar uma pauta de reivindicações unificada a nível nacional, deveria se tirar um calendário de lutas com fatos de rua mensais a nível nacional, deveria se investir principalmente em extensão social a fim de colocar uma consciência realmente anti-capitalista através da prática, tanto nos estudantes como na própria comunidade do qual estão inseridos, e a questão do movimento estudantil como prioridade a resistência contra o neoliberalismo. (militante 7 - Libertário)

Observa-se, porém, que a proposição da luta pelo Fora FHC e Fora FMI, trazida pela militância estudantil filiada aos partidos de esquerda 
enfrenta o descontentamento pela maneira como a maioria das tendências políticas encaminham a questão. A crítica parte dos grupos anarquistas e libertários que mesmo concordando com o conteúdo manifesto da luta, discordam dos encaminhamentos práticos evidenciando uma tensão existente. Esta crítica, além disso, sinaliza também uma reação contra o estilo tradicional do militante que, estando convencido pela racionalidade do problema, fica na retórica e não encaminha políticas de ações e calendário concreto de como os estudantes em movimento irão interferir na questão. O depoimento é ilustrativo nesse sentido:

É obvio que nós somos contra FHC, mas a gente acha que um Fora FHC sem reivindicações específicas dos movimentos populares, são palavras soltas ao vento. Tu dizer Fora FHC o trabalhador realmente não se identifica com aquela palavra solta, aquela frase solta. Se identifica sim com maiores salários, melhores condições de trabalho, um estudante com qualidade no ensino, com todas essas questões, aí daí sim. Então, o quê que acontece, a esquerda em geral ela solta essas palavras Fora FHC e Fora FMI, e o quê que vamos fazer? Vamos tirar o FHC e botar o vice Marco Maciel lá? É complicado, fica uma coisa muito solta, nem um pouco objetiva”. (militante 8 Libertário)

Fica visível a ironia do estudante que não sente por trás deste tipo de protesto a formulação clara de um projeto que consiga trazer uma solução positiva para o campo popular.

A pesquisa junto à militância presente no $46 .{ }^{\circ}$ CONUNE demonstra que não há um único ideário presente no movimento. A pluralidade de visões no interior do movimento estudantil leva ao surgimento de tensões no campo político e os diversos grupos existentes neste campo vão negociando politicamente as demandas e estratégias para suas ações.

\subsection{Novas linguagens e práticas emergentes}

Quando apontamos o distanciamento entre estudantes e entidades pautamos nossa interpretação, principalmente, na realidade mais expressiva do movimento estudantil, e talvez a mais conhecida, a da militância tradicional, com suas estratégias limitadas a um modo de fazer política. Porém, por outro lado, devemos relativizar a falta de participação estudantil e o distanciamento anteriormente observado, se olharmos para as diversas iniciativas que começam a se destacar e tomar corpo.

Mas, o que de fato vem surgindo a partir do intercruzamento do movimento estudantil com outros movimentos sociais? Que experiências estão acontecendo no interior do movimento estudantil a partir da nova confi- 
guração juvenil e suas demandas? Existem novas e outras linguagens que trazem consigo conteúdos e métodos diferentes dos tradicionais, capazes de impulsionar setores estudantis?

Expressões de um período recente, alguns grupos organizados a partir de uma nova lógica de militância surgem no movimento estudantil, revitalizando-o. São signos destas novas linguagens as Executivas de Curso (que apesar de algum tempo de existência somente se fortaleceram e ganharam maior visibilidade na última década), os coletivos de cultura, grupos de estudantes negros, grupos de extensão universitária realizado pelos estudantes, coletivo de mulheres universitárias, etc.

Autônomos, mais democráticos e organizados de uma forma horizontal, esses grupos se fortalecem no interior das universidades como uma nova forma de intervir politicamente, criando ações coletivas que dão respostas às muitas das novas demandas dos estudantes. Estes parecem sinalizar o que Scherer-Warren (1998: 60) aponta sobre a formação de redes:

estas redes de movimentos constroem-se sobre o pano de fundo de múltiplas redes sociais primárias e redes submersas. [...] a formação das redes associativistas locais (a politização) é perpassada pelos elos que se formam nas redes submersas (a cotidianidade) que the dão base.

Estas novas experiências sugerem o surgimento de uma nova sociabilidade militante no movimento estudantil, contrapondo-se às práticas mais tradicionais da militância dos estudantes, reprodutora de um comportamento político institucionalizado e (re)produzida nos espaços de apoio do movimento estudantil como os partidos, sindicatos, etc.

Nesse sentido, fica explícita no depoimento de um dos nossos entrevistados esta nova configuração do movimento estudantil, que se gesta e se fortalece aos poucos:

[...] você não pode mais falar na universidade hoje de movimento estudantil, existem movimentos estudantis. Eu sou defensor que a gente pulverize a representação estudantil pela base. Eu não estou defendendo aqui que a gente crie uma outra organização nacional, não é isso, mas você tem que pulverizar a representação pela base. Então grupos temáticos na universidade que trabalham a questão da cultura, eles representam uma parcela de estudantes, que trabalham a questão do meio ambiente, a questão de gênero, que trabalham a questão de raça, com coisas que a UNE não dá conta, que o centro acadêmico não dá conta... então eu sou defensor de uma tese que pode parecer até utópica, meio sonhadora, mas eu acho que a gente deve pulverizar o movimento estudantil pela base. O movimento estudantil hoje é muito 
mais que as organizações formais, ele é muito mais do que isso. Acho até que as organizações formais já não dão conta de responder as inúmeras interrogações que existem hoje na juventude, na universidade, porque no mundo global neste fim de século, pôs e impõe para nós mais perguntas que respostas. Então nesse sentido é que há na minha opinião uma necessidade da gente pulverizar isso, e tentar conformar uma globalidade de representação a partir dessa diversidade. (militante 4 - Unidade na Luta/PT)

Aspectos como o racial, de gênero, cultura e juventude são incorporados pelos estudantes que desenham além de conteúdos novos, metodologias novas. Sobre a questão metodológica, analisaremos posteriormente com mais detalhe a experiência das Executivas de Curso.

Essa "nova sociabilidade militante" se gesta e se fortalece com o enfraquecimento do modelo tradicional de fazer política, mas principalmente pelas tensões que surgem quando estes dois modelos vêm à tona, ficam latentes.

Grupos no interior do movimento estudantil fazem a crítica ao modelo tradicional que já não consegue contemplar a nova configuração estudantil. No grupo temático de gênero e raça, a reivindicação para que, de fato, o movimento assuma também as causas das minorias e não se isole em assuntos extremamente específicos da universidade.

Hoje existe no movimento estudantil o estudante chamado político e o academicista que só trabalha a questão da universidade, e andamos esquecendo que o movimento estudantil é bem maior do que isso... ele é da sociedade. Precisamos ter consciência de que precisamos fazer movimento estudantil para a sociedade e não só para a universidade. Hoje as polêmicas são vividas no próprio movimento estudantil. Hoje ele não debate a questão racial, ele se nega a discutir. Quando teve a comemoração do dia da consciência negra, em Belém do Pará, colocamos nossas propostas de cotas para negros... e todas as tendências políticas da universidade caíram em cima da gente. Eles falavam que era um assunto polêmico. E na verdade a gente tem que criar polêmica pra todo mundo saber que os negros são ainda excluídos nas universidades de Belém do Pará, não só lá, mas em todo o Brasil. (Integrante do Grupo de discussão sobre gênero e raça)

Assim, os estudantes negros também se organizam nos fóruns estudantis de maneira a reivindicar uma maior atenção para a sua realidade de exclusão. No início da década de 90, o coletivo de negros universitários apresentou uma contribuição escrita "sobre a questão étnico-racial, econômica, política e educacional do povo negro brasileiro" (A universidade que o povo negro quer: 01). Intitulado: "Universidade: tempos negros virão [...]. A universi- 
dade que o povo negro quer", este documento novamente trazia o questionamento da diferenciação de oportunidades a partir da questão racial. Mesmo sendo maioria da população, poucos são os negros que conseguem chegar ao nível superior. Assim, os universitários negros denunciam a universidade como um dos lugares sociais onde se reproduzem "os valores da estrutura racista da sociedade brasileira" (ibid).

\section{Continuam:}

Há muito se ouve falar da necessidade de incorporação por parte do movimento estudantil de questões outras: ecologia, feminismo, drogas, serviço militar obrigatório etc. No entanto, em momento algum as correntes políticas do movimento estudantil sequer levantam a problemática étnica-racial nas suas bandeiras de luta. Porém, para a efetivação de um projeto que vise uma mudança no sistema educacional do Brasil, é necessário que a UNE e o movimento estudantil absorvam como condição sine qua non um projeto contra-hegemônico e anti-racista para a nossa sociedade (ibid).

Não sem motivos os estudantes negros começam a se articular, ainda que de maneira tímida. A realidade de exclusão dos negros no ensino superior é visível. De acordo, com Martins (2003), "os negros na Universidade de São Paulo (USP) são apenas 1,3\% dos 39 mil alunos. Este dado é irrisório num país onde $45 \%$ da população é negra". Neste sentido, a discussão por ações afirmativas que sejam capazes de incluir os negros no ensino superior - como as cotas - tem sido uma temática muito presente no movimento estudantil brasileiro atualmente.

Assim, grupos temáticos vão fortalecendo-se e pulverizando-se como alternativas de expressão estudantil, capazes de mobilizar e atrair estudantes. $\mathrm{Na}$ resignificação das lutas, na criação da polêmica enquanto possibilidade efetiva de discussão, o espaço para favorecer o surgimento de uma metodologia e conteúdos novos no interior do movimento.

Partindo das características desta "nova sociabilidade militante", observarmos mais de perto a experiência das Executivas de Curso, e mais especificamente, a Executiva de Curso de Agronomia - a Federação de Estudantes de Agronomia do Brasil (FEAB).

As Executivas de Curso $^{8}$ surgem em sua maioria na década de 70, a princípio para debater questões e problemas corporativos. Com o passar

\footnotetext{
${ }^{8}$ As Executivas de Curso são também conhecidas como movimento estudantil de área, isto é, um movimento organizado pelos estudantes a partir de cada área do conhecimento. Nesse sentido, existem Executivas em quase todos os cursos. Assim, dependendo do grau de participação e mobilização dos estudantes, a Executiva terá maior ou menor visibilidade na universidade, bem como no próprio movimento.
} 
do tempo, algumas delas se fortalecem e criam vínculos com outros movimentos sociais, formulando novas políticas (mais amplas) para a entidade. A aliança de temáticas específicas dos cursos (currículos, avaliação, qualidade dos cursos, entre outros) com questões políticas de âmbito mais geral, consegue ser uma das chaves de leitura para compreendermos o sucesso das executivas perante os estudantes. Como descreve Mische (1996: 28),

Nos encontros nacionais das executivas, são discutidas questões concretas sobre a organização dos cursos e a reforma universitária, além do papel social do profissional e propostas alternativas para políticas públicas (como a proposta elaborada pela Denem, a executiva de Medicina para avaliação universitária). Muitas das executivas têm inserção em movimentos sociais, com o movimento dos sem terra, no caso da Agronomia (a Feab, a executiva mais antiga do país, se destaca pela organização de estágios de vivência, que levam estudantes para conhecer a realidade dos acampamentos), além do movimento de saúde, no caso de enfermagem e medicina, ou educação popular, no caso da pedagogia.

É nesse contexto que se insere a FEAB, e a partir de sua experiência enquanto executiva, analisaremos: a) sua metodologia para atrair os estudantes e discutir a política da entidade, e; b) o conteúdo manifesto por ela (temas abordados, ideário político, etc.).

$\mathrm{Na}$ tentativa de entender, estudar a temática da juventude (seus problemas, perspectivas e, principalmente, a crise de valores coletivistas), a FEAB promoveu um Encontro Nacional dois meses após o $46 .^{\circ}$ CONUNE para discutir a relação Juventude - Sociedade. ${ }^{9} \mathrm{O}$ debate central do encontro problematizou o fato do movimento estudantil ser constituído por uma parcela significativa de jovens, situado na atual crise de mobilização estudantil que também é juvenil. Diante disso questionava-se: a) como a juventude pode recriar-se para depois construir um novo modelo de sociedade? b) como pensar as saídas alternativas de aproximação entre o próprio movimento estudantil e os estudantes?

O encontro deixou claro que existe um grande esforço de uma parcela da juventude em não se deixar levar pelos valores vigentes que "a mídia” conseguiu difundir. Porém, a difusão pela mídia, e do próprio sistema educacional, de valores como o consumo, competitividade, competência, qualidade, individualismo, pragmatismo etc. - marca do ideário

\footnotetext{
9 Encontro intitulado: Juventude em busca de novos valores. Agosto/Setembro de 1999 Pelotas/RS.
} 
neoliberal, cada vez mais forte no senso comum - facilita e permite que os jovens não consigam se organizar com tanta força e expressão como gostariam.

Em um dos relatos podemos observar este ponto de maneira mais clara.

[... a juventude hoje, a classe como um todo ela está com a mesma formação, com os mesmos valores, com essa questão enrustida já (valores individualistas), porque ela não vem só da educação, ela vem da sociedade, do mundo, da mídia, da forma como é conduzida a formação da pessoa, sabe? Então isso é complicado de você resgatar esses valores ou mesmo não seria tanto resgatar, porque tem valores que nem deveriam ser resgatados, mas de construir novos valores pra essa juventude, pra esses futuros profissionais, futuros... pessoas que vão estar no mundo lá fora... e com certeza essas pessoas terão que fazer a diferença, porque não adianta nada a gente trabalhar por um longo período e chegar ao final e ver estas pessoas se perdendo como acontece... é uma característica do movimento... (Dirigente da FEAB)

Ao mesmo tempo, as Executivas de Curso já são portadoras de uma dinâmica que ajuda a atrair o jovem estudante à participação no próprio movimento e nas discussões políticas que este facilita. Organizada nacionalmente, a FEAB estabelece mecanismos criativos para estabelecer um contato maior com os estudantes trazendo, de certa maneira, uma dinâmica diferenciada da existente no movimento estudantil geral ${ }^{10}$.

Em sua estrutura contempla uma Direção Nacional, cinco Regionais e vários Núcleos de Trabalho Permanente (NTPs) que são núcleos de estudo, formado por coletivos de estudantes, que têm a função de subsidiar o movimento em suas discussões, socializando e criando textos, etc. Existem os NTPs de movimentos sociais, agroecologia, documentação e arquivo, entre outros. Mesmo assim, podemos pontuar que nem sempre estes dão conta da dinamicidade da realidade do movimento.

Com uma periodicidade anual, o movimento estudantil de agronomia, realiza seu principal fórum, o Congresso Nacional de Estudantes de Agronomia (CONEA), utilizando-se de uma metodologia que permite uma integração maior entre os estudantes. Alternando momentos de debates com momentos mais "lúdicos" os estudantes conseguem estabelecer um vínculo maior entre si, de maneira a se fortalecerem a identidade e coesão do grupo.

${ }^{10}$ Como já observamos, quando nos referimos ao movimento estudantil geral, estamos nos referindo às entidades clássicas como os Centros Acadêmicos, Diretórios Centrais, etc., que possuem uma dinâmica específica. É caracterizado por ser um movimento mais massificado, heterogêneo, além de fragmentado. 
Realizando oficinas em pequenos grupos, durante os dois primeiros dias de encontro, os estudantes debatem acerca das mais variadas temáticas: desde a agroecologia à desenvolvimento rural, da participação do movimento em encontros internacionais à realidade agrária latino americana, entre outros. As temáticas mais importantes e, por isso, colocadas em destaque, são discutidas pelos estudantes em mesas redondas já previamente programadas. No momento anterior a estas, o movimento realiza o que os militantes denominam de mística ${ }^{11}$. A mística do movimento é um momento de sensibilização da plenária, onde de maneira mais "celebrativa" ou "reflexiva" são colocadas questões sociais e políticas que pensam a América Latina, principalmente em seus aspectos agrários. A luta pela terra, a memória de mártires latinoamericanos que significam a luta por justiça, a construção de uma nova sociedade marcada pela inclusão, são algumas "categorias" ou símbolos usados neste momento.

Assim também os estudantes vão resignificando suas práticas e incorporando elementos novos advindos de outros movimentos sociais. Além do uso de uma metodologia diferenciada do movimento estudantil clássico, a Executiva de Agronomia se destaca por outras experiências. Com "um pé na universidade e outro na comunidade", a FEAB tenta sensibilizar os estudantes para práticas de intervenção que tenha o objetivo de transformação social. Com um ideário e caráter emancipatórios vão desenhando experiências educativas/formativas e trabalhando com políticas de extensão. Neste sentido, destacamos a realização do Estágio de Vivência.

A atividade do estágio de vivência tem um caráter de sensibilizar politicamente o estudante para a realidade de pobreza e exclusão de vários trabalhadores rurais sem terra, bem como, para a situação precária dos pequenos agricultores. A opção de estimular a realização de um projeto com estes trabalhadores rurais e com a agricultura familiar é fundamentalmente política. Participar do estágio de vivência é experienciar uma realidade diferente, marcada pela convivência com pessoas simples e, muitas vezes, com costumes e hábitos culturais totalmente diferenciados. Para os estudantes

\footnotetext{
${ }^{11}$ A realização da mística em seus encontros foi incorporada pelo movimento estudantil da FEAB através de sua intensa interlocução com os movimentos sociais do campo, em especial, com o Movimento dos Trabalhadores Rurais Sem Terra - MST. Este último, tem em seu repertório de ação coletiva, o momento da mística, herança da prática das comunidades eclesiais de base da igreja católica, um dos grupos fundadores do movimento. Não iremos aprofundar esta temática, mas a realização da mística no movimento tem sido essencial para a criação de uma forte identidade coletiva e coesão do grupo. A mística, apesar de ter sua dimensão reflexiva - e trazer à tona a história da trajetória do movimento - suas conquistas, desafios, etc., trabalha muito mais a dimensão das emoções, dos sentimentos entre os participantes.
} 
torna-se mais um instrumento de luta contra os valores neoliberais, constantemente debatidos nos encontros e um momento de resgatar ou criar novos valores que se dirigem à questão da coletividade.

A experiência é uma tentativa de conscientizar politicamente os jovens estudantes que, ao entrar em contato com uma outra realidade, pode ser capaz de atuar e intervir na perspectiva de valores como a solidariedade, participação e ética. Desta forma, é também uma maneira de "combater" a formação de práticas individualistas entre os estudantes, práticas estas diagnosticadas pelos membros da FEAB na fala anterior.

Para um dos dirigentes da FEAB, o estágio de vivência é:

uma coisa essencial, principalmente para o estudante, porque hoje você tem um estudante que tem esses valores, que se perderam... porque o estudante hoje se cria na cidade, nasce no asfalto, mora no apartamento onde ficam acentuados principalmente os valores individualistas e quando ele entra na faculdade ele não consegue fazer essa quebra de valores. Um estágio de vivência consegue colocar o estudante em choque com outra realidade, é uma realidade diferente, que força o cara pensar criticamente. $\mathrm{Na}$ nossa visão esse é um dos principais ganhos que a gente tem com o estágio de vivência. Se vocêe é acostumado, no caso da agronomia, a ver grandes tratores, grande colheitadeira, veneno, bababá, e o latifúndio... qual seja a hora em que ele vai para um assentamento, uma área indígena, uma associação de pequeno produtor... aquilo é contrastante com a realidade do cara. O cara se põe a pensar no quê que ele está aprendendo, se põe a pensar pra quem ele está aprendendo, nossa... Então se você consegue aglutinar em cima do estágio de vivência, nossa é um ganho enorme. Você faz com que a pessoa veja a realidade, o quê que existe do portão para dentro da universidade e do portão para fora da universidade... Porque isso (comportamento) não vem só da criação da pessoa, a sua origem, mas da universidade também, o direcionamento que ela dá, a linha dos professores, como está sendo conduzido o próprio curso, e a quem a universidade atende principalmente [...] Sem dúvida, a pessoa que vai ao assentamento, nunca mais vai ser a mesma. (Dirigente da FEAB).

Assim, de maneira não massificadora e com um trabalho mais organizado, estudantes vão desenhando ações políticas com outros setores, recriando novas possibilidades de intervenção. Vão sendo sujeitos protagonistas de sua própria ação, tecendo com outras organizações, redes de intercâmbio e de atuação política ainda que estas ações devam ser problematizadas quando relacionadas com o movimento estudantil geral.

Hoje, a experiência se renova e amplia para a participação de outros estudantes. Em alguns estados, o movimento estudantil geral incorporou o estágio de vivência como uma de suas atividades. E com uma nova roupagem, 
participam do estágio de vivência estudantes não só do curso de agronomia, mas de todas as áreas do conhecimento, transformando-o numa experiência interdisciplinar.

Organizam-se também, neste sentido, as Executivas de Curso da área de saúde. Ainda em processo de elaboração, estas Executivas - com apoio integral do Ministério da Saúde do novo governo federal - se propõem a realizar esta experiência de intervenção no Sistema Único de Saúde (SUS), sistema que congrega hospitais públicos, prontos socorros, associações de atendimento à população, etc.

Assim, além de ter um cunho formativo no desenvolvimento profissional destes estudantes, o estágio de vivência propicia algo mais que isso; ele desempenha um papel educativo e de formação política, chamando os estudantes para uma atuação mais comprometida com os segmentos populares.

Portanto, com uma atuação destacada a partir destas diferentes experiências, podemos afirmar que as Executivas de Curso, apesar de sua grande heterogeneidade, tem muito a contribuir na construção de novos espaços de participação dos estudantes no movimento estudantil.

Outra dimensão acentuada enquanto uma nova forma de fazer coletivo no movimento estudantil é a dimensão da cultura. No final da década de 90 aposta-se na cultura no movimento estudantil para atrair as forças juvenis dispersas. Numa época, onde a diversão e o lazer são privilegiados, é importante construir espaços de manifestação cultural capazes de aglutinar e de transformar a crítica social individual em ação coletiva.

Nesse intuito, a UNE, por uma demanda e preocupação das bases estudantis, passou desde 1999, a realizar o que foi chamado de Bienal de Cultura. Esta surgiu da necessidade da construção de um espaço que, como dissemos acima, fosse capaz de atrair as redes juvenis dispersas, conectando-as.

Diferente dos Centros Populares de Cultura (CPCs) dos anos $60^{12}$, a Bienal tem um caráter diferenciado ${ }^{13}$. A cultura aparece não mais com o

\footnotetext{
12 Os CPCs surgiram na década de 60 numa articulação do movimento estudantil com movimentos artísticos-culturais. Sua principal função era, através da arte, politizar os trabalhadores e a sociedade em geral. Com o apoio do governo popular de João Goulart, esta experiência se multiplicava em vários lugares do país, e teve como ponto-chave a crítica social e a mobilização para a realização de uma Reforma Universitária. Com o advento da ditadura, em 1964, esta experiência assume um discurso de contraposição e embate ao governo militar.

${ }^{13}$ A Bienal de Cultura da UNE, é um evento realizado de dois em dois anos que visa mostrar a produção artística realizada nas universidades pelos estudantes nos seus mais diversos âmbitos: cinema, dança, teatro, literatura, poesia, etc. Tem também a preocupação de ser um espaço de discussão sobre temáticas como: Ciência e Tecnologia, Educação e Ensino Superior, etc. As Bienais contam com a participação de outros grupos juvenis (hip hop, capoeira, grupos circenses, etc.),
} 
objetivo puro e simples de "conscientização" do povo, ou seja, como um instrumento pedagógico de formação política. Mais do que "usar" a cultura como meio de transformação das consciências e do próprio meio, a Bienal surge como um espaço de resgate do político que se apresenta disperso nas mais variadas expressões e redes estudantis.

$\mathrm{Na}$ década de 60, os estudantes eram os sujeitos históricos que iriam politizar a sociedade brasileira. Na década de 90 , os estudantes dispersos significam a cultura como meio e possibilidade de encontro deles mesmos com seus projetos. Na concretização do encontro, o aparecimento do político e da crítica social. Na manifestação artística os estudantes mostram que "mais do que querer mudar o país, eles querem compreendê-lo" ${ }^{14}$.

Ao fazer isso, propõem também saídas para a própria realidade cultural existente no país. A Bienal serve como um circuito alternativo de expressões de diversos matizes: cinema, música, dança, teatro, literatura, vídeo, entre outros. O mercado cultural é denunciado, e com ele, a crítica da massificação cultural e a falta de investimento por parte do governo num dos pilares da soberania nacional. A ditadura econômica, que se manifesta no mercado cultural através de projetos massificadores, é combatida.

A carta de Ouro Preto, que lança a 2. ${ }^{a}$ Bienal de Cultura da UNE, expressa um pouco essa idéia.

\section{CARTA DE OURO PRETO - NOSSA CULTURA EM MOVIMENTO $1^{\circ}$ Circuito de Cultura Universitária da UEE/MG - Lançamento da $2^{\mathrm{a}}$ Bienal da UNE}

Mãos que vão tirar cada tijolo da cela do silêncio e romper os muros da prisão em que se transformou a indústria cultural. Luzes acesas em meio à escuridão deste final de milênio. Água que jorra das minas numa época de torneiras secas. Chaves para abrir as portas da participação. Arte não é remédio falso. Jovem não é otário. Trabalhador não é lixo. Por isso o Circuito está no centro de um cruzamento que vai ligar o artista, o público, o patrocinador, a arte, o indivíduo e o coletivo. Ela vai no fundo, do fundo, do fundo, se for para trazer o diamante de diferença, da independência e da mudança. Afinal produtor cultural não tem que se resignar com papel de cão de guarda do neoliberalismo. Como orvalho não enche o poço, a UNE estará provocando

personalidades e artistas de âmbito nacional, bem como representantes da cultura popular da cidade que acolhe a Bienal (poetas populares, grupos folclóricos, etc.). Até o momento foram realizadas três Bienais (Salvador, 1999; Rio de Janeiro, 2001; Recife, 2003), sendo a quarta programada para janeiro de 2005 em São Luís - MA.

${ }^{14}$ Fala do cantor Chico César que participou da 1. ${ }^{a}$ Bienal realizada em Salvador, em 1999. Caderno da Bienal. 
uma chuva de esperança que fará brotar a semente da transformação. Um terremoto cultural que abalará os alicerces da hipocrisia e do comercialismo estúpido e vulgar. A manipulação da informação, a uniformização, a pasteurização, enfim, a reprodução do mesmo não vem do acaso. Elas existem para apagar os países, afogar a soberania e identidade do povo num mar de lama, podridão e ignorância. Lutamos por uma arte e uma cultura onde não predomine o banal mortal, a esquizofrenia, o miolo mole e a intransigência elitista. Queremos que a arte e a cultura tenham abrigo certo ao invés de serem despejadas. Pela criação de um movimento artístico/cultural em defesa da soberania, da identidade nacional e da cultura popular. Queremos política cultural desenvolvida pelo Estado, que ponha fim ao balcão de negócios em que se transformou o Ministério da Cultura. Pela democratização da produção, do acesso e da difusão da cultura. Todos a $2^{a}$ Bienal da UNE em fevereiro de 2001 no Rio de Janeiro.

Ouro Preto, 15 de Julho de 2000

Realça-se também aqui, a importância da dimensão simbólica e cultural na compreensão destas novas relações. A dimensão visual e estética é um importante aspecto desta nova sociabilidade. A roupa, a indumentária, os painéis, as performances, etc., continuam sendo, como no passado, elementos importantes para comunicar e decodificar as intenções políticas de cada grupo. A aparição de símbolos e mitos nas expressões de estilo também permanece como elemento de comunicação entre os estudantes. A arte se torna um campo de expressão cada vez mais presente, surgindo como meio de denúncia, protesto, mas também de organização frente às possibilidades de intervenção no futuro. Neste sentido, suas ações políticas assumem um tom performático e teatralizado, um tom espetacular e de espontaneidade.

Porém, é preciso ressaltar que este aspecto pode ser resignificado atualmente num contexto de uma concepção política enquanto espetáculo, como aponta Ribeiro (1994). Há uma supervalorização do aspecto estético que assume dimensões espetaculares no intuito de atrair e envolver "espectadores”. O espetáculo pode ser premeditado ou espontâneo, contar com maior ou menor infra-estrutura, dirigir-se à consciência crítica ou alienada, mas é sempre performático.

E o destaque é importante porque, grupos mais tradicionais do movimento estudantil fazem uso do instrumental artístico enquanto espetáculo sob a perspectiva da tecnização da política. No processo de "profissionalização da política" (Negt e Kluge, 1999) torna-se cada vez mais necessário o uso de um instrumental tecnológico e visual que sirva como técnica de convencimento. É o caso do recurso ao marketing. 
Contudo, é importante destacar que, apesar de existir uma apropriação do estilo performático de fazer política também pelo movimento estudantil tradicional - seja pelo uso do marketing, seja pelo simples apelo visual esta apropriação se inscreve numa outra lógica, a do convencimento, se diferenciando da lógica dos grupos menos institucionalizados que trazem consigo uma perspectiva de crítica e protesto nestas manifestações. Nesse sentido, os estudantes (principalmente os que não participam se identificam com o movimento estudantil tradicional), conseguem fazer a crítica a esse recurso enquanto mera técnica de convencimento, mero instrumento de adaptação/cooptação.

Neste sentido, podemos afirmar também que as teatralizações do protesto, da denúncia e da proposta - que estão cada vez mais presentes nas suas manifestações políticas - apesar de serem muitas vezes caracterizadas pela sua espontaneidade e especificidade são muito ricas e significativas em termos simbólicos. A "apropriação" da arte e cultura no interior do movimento torna-se assim, um importante instrumento de retomada e participação dos estudantes.

Estas dinâmicas performáticas, na verdade, extrapolam quaisquer práticas juvenis, bem como o próprio campo da política, inserindo-se na lógica da sociedade do espetáculo e da comunicação.

O que fica da observação da militância nestes diferentes espaços é que a juventude universitária, em suas mais variadas expressões, tenta romper com estruturas dominadoras e torna-se, das mais diferentes formas possíveis e com suas mais variadas práticas, um sujeito coletivo que protagoniza desejos de transformação social.

\section{Desta maneira...}

Nossa pesquisa teve como objetivo identificar na estrutura e organização do movimento estudantil, conteúdos e formas que nos indicassem o surgimento de uma nova sociabilidade militante.

Desta forma, procuramos investigar através do movimento estudantil institucionalizado, as suas mais diversas expressões, ora no modelo tradicional, ora nas formas inovadoras nas quais ele aparece, partindo da perspectiva de que há uma dinâmica plural no seu interior que evidencia a presença de diversos movimentos estudantis.

No estudo pudemos perceber que existem no movimento estudantil práticas e conteúdos novos que apontam para o surgimento desta nova sociabilidade. É nesse contexto que se originam no interior do movimento, grupos que se organizam para tentar implementar pautas mais diferenciadas das 
clássicas e globais. As temáticas da causa negra, de gênero, da cultura, da paz, do primeiro emprego, entre outros, começam a ser implementadas e debatidas nos Congressos da UNE.

As experiências variadas de expressões estudantis vão crescendo e amadurecendo em meio a uma diversidade de articulações. O movimento estudantil ao tentar se expressar por outras vias que não somente a tradicional, passa por um processo de ampliação de sua identidade. A fragmentação e dispersão acentuadas, características dos anos 90, se expressam na identidade do movimento estudantil e suas ações se pulverizam. Sem perceber, os militantes criam novas relações e, porque não dizer, criam novos movimentos estudantis. A idéia de um movimento único continua enquanto organização, mas as frentes se ampliam enquanto possibilidades de atuação. A emergência destas práticas se expressa através de características tanto estruturais quanto simbólicas.

Sobre o primeiro aspecto, podemos afirmar que diferentemente do movimento estudantil clássico, portador de uma estrutura organizativa muitas vezes rígida e hierárquica, o movimento hoje também se caracteriza pela constituição de coletivos que trazem uma novidade em termos de organização postulando uma participação mais democrática, autônoma e horizontalizada.

Com uma forma de participação mais direta, os grupos que defendem essas novas práticas atuam de maneira mais qualificada para proporem e realizarem um processo educativo que vincula a política ao exercício da capacidade de discernimento e cria a possibilidade de outras relações de medida baseadas na coletividade como princípio para a emancipação dos indivíduos e da sociedade (Negt e Kluge, 1999).

Isso fica evidente, por exemplo, na estrutura das Executivas de Curso, que privilegia em seus fóruns, a discussão em pequenos grupos em detrimento da realização de encontros e seminários massificadores. O contato direto e mais informal dos dirigentes das entidades com os estudantes, bem como, os espaços culturais que facilitam um maior entrosamento entre os mesmos, destacam a concepção assumida que rompe com a dicotomia entre a ética da militância e a subjetividade dos militantes, muito presente no formato de organização tradicional, como destaca Mische (1996).

Uma experiência importante que se configura nesse novo formato organizativo é o Estágio de Vivência. Esta experiência tem demonstrado que a estrutura organizativa aliada a uma postura política voltada para a realidade social pode colaborar no processo educativo dos estudantes. Levando os mesmos a comunidades rurais, os estágios de vivência têm o mérito de conseguir, a partir de práticas ligadas à extensão, formar e sensibilizar politi- 
camente os estudantes para questões relativas a realidade social de pobreza e exclusão. Neste sentido, o investimento na organização de práticas de extensão é um projeto de ação envolvente para o movimento. Isto porque, em primeiro lugar, traz maior qualidade à formação dos estudantes, ao aliar teoria e prática, no enfrentamento de problemas concretos. Em segundo lugar, porque a sensibilização para as questões sociais certamente concorre para o desenvolvimento de uma consciência crítica e amadurecimento político.

A retomada da cultura enquanto elemento de associação e participação estudantil também é outro destaque nesses novos coletivos que se formam. Não só a retomada da arte, mas a apropriação de um novo jeito de se manifestar: de maneira mais performática e dando importância a aspectos simbólicos que ajudam a fortalecer a identidade coletiva do movimento, como é o caso da mística.

A emergência de novas práticas no interior do movimento estudantil sinaliza o desgaste de uma forma tradicional de fazer política que não contempla a diversidade e anseios desta juventude.

Portadoras de projetos coletivos, estas experiências conseguem amenizar o distanciamento entre estudantes e entidades estudantis. Isto é possível, sobretudo, pelo fato de conseguirem se situar como contraponto às práticas tradicionais, estruturantes de um babitus político baseado numa concepção centralizadora, hierárquica e burocrática.

É importante ressaltar que a emergência destas temáticas no interior do movimento estudantil, não se faz sem antagonismos e conflitos. Porém, mais que antagônicas essas novas práticas são complementares e oferecem a uma boa parcela de jovens estudantes, um importante espaço de socialização política. O surgimento de novas formas de ação, e expressão, não significa que as práticas anteriores tenham sido totalmente superadas. As novas linguagens ainda estão em formação precisando, portanto, fortalecer seus coletivos e práticas, bem como resistir às pressões das forças hegemônicas, as quais até por suas características podem tentar forçar uma unidade, sufocando-as.

A estrutura das entidades, com sua prática política tradicional, continua hegemônica, mas já não consegue aglutinar e mobilizar a maioria dos estudantes, que inscritos numa outra lógica, não se sentem representados pelos grupos que participam daquele campo político. Nesse sentido, precisa rever concepções e estratégias, alimentar-se de novas experiências a fim de levar a cabo seus projetos de transformação social. 


\section{Referências Bibliográficas}

Albuquerque, J. A. G. (1977a), Movimento estudantil e consciência social na América Latina. Rio de Janeiro: Paz e Terra.

Albuquerque, J. A. G. (1977b), “Movimento estudantil e classe média no Brasil - estudo comparativo”, in J. A. G. Albuquerque (org.), Classes médias e política no Brasil. Rio de Janeiro: Paz e Terra.

Bourdieu, P. (1998), O poder simbólico. Rio de Janeiro: Bertrand Brasil.

Cardoso, I. (1990), “Memória de 68: Terror e interdição do passado”, Tempo Social Revista de Sociologia da USP, 2(2).

Cardoso, I. (1998), “O discurso da Universidade”, Tempo Social - Revista de Sociologia da USP.

Folha de São Paulo (2003), "Projeções indicam que alunos mais pobres serão responsáveis pelo maior crescimento de demanda por vagas no ensino superior. Cotidiano. 03 de agosto.

Foracchi, M. M. (1972), A juventude na sociedade moderna. São Paulo: Pioneira (Ed. da Universidade de São Paulo).

Foracchi, M. M. (1977), O estudante e a transformação da sociedade brasileira. São Paulo: Editora Nacional.

Martins, R. (2003), "Haverá conflito”, Revista Época, 267, 30 de junho.

Martins Filho, J. R. (1987), Movimento estudantil e ditadura militar. Campinas: Papirus.

Martins Filho, J. R. (1996), Rebelião estudantil: 1968 - México, França e Brasil. Campinas: Mercado de Letras.

Martins Filho, J. R. (1998), 1968. São Paulo: Cortez Editora.

Matos, O. C. F. (1989), Os arcanos do inteiramente outro: a Escola de Frankfurt, a melancolia e a revolução. São Paulo: Brasiliense.

Melucci, A. (1997), "Juventude, tempo e movimentos sociais", Revista Brasileira de Educação. S. Paulo: ANPED.

Mische, A. (1996), "Redes de jovens", Revista Teoria e Debate, 31.

Negt, O.; Kluge, A. (1999), O que há de política na política?. São Paulo: Fundação Editora da UNESP (FEU).

Ribeiro, R. J. (1994), “A política como espetáculo”, in Evelina Dagnino (org.), Os anos 90: política e sociedade no Brasil. São Paulo: Brasiliense.

Sanfelice, J. L. (1986), Movimento estudantil: a UNE na resistência ao golpe de $64-$ antecedentes (início da década de 60: a presença da UNE nos acontecimentos políticos. Parte 1). Campinas: Reflexão.

Scherer-Warren, I. (1998), “Ações coletivas na sociedade contemporânea e o paradigma das redes”, Sociedade e Estado: Urbano: novos olbares sociológicos, XIII(1).

Sousa, J. T. P. de (1999), Reinvenções da utopia: a militância política de jovens nos anos 90. São Paulo: Hacker Editores. 


\section{Periódicos Estudantis}

Revista Especial sobre a 1 ${ }^{a}$ Bienal de Cultura da UNE. 1999.

Tempos negros virão: a universidade que o povo negro quer. $42 .{ }^{\circ}$ Congresso da UNE. 1992.

\section{Endereços electrónicos}

União Nacional dos Estudantes. Carta de Ouro Preto. Disponível em: <www.une.org.br>. Acesso em 15 de setembro de 2000.

Universidade Vale do Acaraú. Disponível em: <http://www.uvanet.br/projeto_rondon/ novo_rod.html>. Acesso em 10 de agosto de 2003. 